FITRAH Jurnal Kajian Ilmu-ilmu Keislaman

Vol. 05 No. 1 Juni 2019

e-ISSN : 2460-2345, p-ISSN: 2442-6997

Web: jurnal.iain-padangsidimpuan.ac.id/index.php/F

\title{
THE EFFECT OF MATHEMATICS ON HERITAGE CALCULATIONS THROUGH PROBLEM-BASED LEARNING IN MA PONDOK PESANTREN AL-AZHAR BIIBADILLAH TAHALAK KECAMATAN BATANG ANGKOLA
}

\section{MASDELIMA AZIZAH SORMIN, MIRA RAHMA YANTI SORMIN}

Universitas Muhammadiyah Tapanuli Selatan

Email: masdelima@um-tapsel.ac.id,mira.rahmayanti@um-tapsel.ac.id DOI: http://dx.doi.org/10.24952/fitrah.v5i1.1811

\begin{abstract}
This study aims to see the extent of the influence of mathematics in everyday life, one of which is the calculation of inheritance through problem-based learning. This research was conducted at the Al-Azhar Islamic Boarding School in Al-Azhar Islamic Boarding School in Tahalak, Batang Angkola District. This type of research is quasi-experimental research. The population in this study were all students of class XI MA Al-Azhar Islamic Boarding School in Biibadillah Tahalak Batang Angkola District. While the sample taken was class $\mathrm{XI}^{2}$ as many as 20 people as well as the experimental class and class $\mathrm{XI}^{1}$ as many as 20 people as well as the control class. Sampling is done through the pupose sampling technique. The research instrument used was a test of students' mathematical abilities in the calculation of inheritance. Statistical hypothesis testing in this study used the $t$ test. Improving students' mathematical abilities in inheritance calculations that obtain problem-based learning is higher than students who use ordinary learning. The increase in students' mathematical abilities in the experimental class inheritance calculation was 71.6 with the highest score of 90 and the lowest value of 48 with a standard deviation of 10.57 while the ordinary learning class was 66 with the highest value of 80 and the lowest 54 and the standard deviation of 8.485. From the results of the posttest test, it can be seen the influence of mathematics on inheritance calculations through a problem-based learning model with the calculation of $\mathrm{F}_{\text {count }}=0.111$ with a level of $\alpha=0.05$ and $\mathrm{dk}=20$ $2=18$ obtained by $F_{\text {table }}=0.048$. Thus obtained $F_{\text {count }}>F_{\text {table }}$ or $0.111>0.048$, so $\mathrm{Ha}$ is accepted and Ho is rejected. To see the response of students from the results of student observations obtained tcount $=1.85$ and at the level of $\alpha=0.05$ and $\mathrm{dk}=20+20-2=38$ obtained $\mathrm{t}$ table $=1.54$. Thus it is obtained that $\mathrm{t}_{\text {count }}>\mathrm{t}$ table or 1.85>1.54, so Ho is rejected and Ha is accepted.
\end{abstract}

Keywords: Inheritance Mathematics, Problem Based Learning.

Abstrak

Penelitian ini bertujuan untuk melihat sejauh mana pengaruh matematika dalam kehidupan sehari-hari, salah satunya dalam perhitungan warisan melalui pembelajaran berbasis masalah. Penelitian ini dilaksanakan di MA Pondok Pesantren Al-Azhar Biibadillah Tahalak Kecamatan Batang Angkola. 
FITRAH Jurnal Kajian Ilmu-ilmu Keislaman

Vol. 05 No. 1 Juni 2019

Jenis penelitian ini adalah penelitian eksprimen kuasi. Populasi dalam penelitian ini adalah seluruh siswa kelas XI MA Pondok Pesantren Al-Azhar Biibadillah Tahalak Kecamatan Batang Angkola. Sedangkan sampel yang terambil adalah kelas $\mathrm{XI}^{2}$ sebanyak 20 orang sekaligus sebagai kelas eksperimen dan kelas $\mathrm{XI}^{1}$ sebanyak 20 orang juga sekaligus sebagai kelas kontrol. Pengambilan sampel dilakukan melalui teknik pupose sampling. Instrument penelitian yang digunakan adalah tes kemampuan matematika siswa dalam perhitungan warisan. Pengujian hipotesis statistik dalam penelitian ini menggunakan uji t. Peningkatan kemampuan matematika siswa dalam perhitungan warisan yang memperoleh pembelajaran berbasis masalah lebih tinggi dibandingkan dengan siswa yang menggunakan pembelajaran biasa. Peningkatan kemampuan matematika siswa dalam perhitungan warisan kelas eksperimen sebesar 71,6 dengan nilai tertinggi 90 dan nilai terendah 48 dengan standar deviasi sebesar 10,57 sedangkan kelas pembelajaran biasa sebesar 66 dengan nilai tertinggi 80 dan terendah 54 serta standar deviasinya sebesar 8,485. Dari hasil tes postest dapat dilihat pengaruh matematika terhadap perhitungan warisan melalui model pembelajaran berbasis masalah dengan perhitungan Fhitung $=0,111$ dengan taraf $\alpha=0,05$ dan $\mathrm{dk}=20-2=18$ diperoleh $\mathrm{F}_{\text {tabel }}=0,048$. Dengan demikian diperoleh Fhitung $>F_{\text {tabel }}$ atau 0,111 >0,048, sehingga Ha diterima dan Ho ditolak. Untuk melihat respon siswa dari hasil observasi siswa diperoleh thitung $=1,85$ dan pada taraf $\alpha$ $=0,05 \mathrm{dan} \mathrm{dk}=20+20-2=38$ diperoleh tabel $=1,54$. Dengan demikian diperoleh bahwa thitung $>$ tabel atau 1,69 $>1,54$, sehingga Ho ditolak dan Ha diterima.

Kata Kunci: Matematika Warisan, Pembelajaran Berbasis Masalah

\section{PENDAHULUAN}

Matematika merupakan salah satu mata pelajaran di sekolah yang dapat digunakan untuk mencapai tujuan tersebut. Matematika juga merupakan bahasa simbol atau bilangan, misalnya: penjumlahan, pengurangan, perkalian dan pembagian. Oleh sebab itu matematika sangat diperlukan baik untuk kemajuan IPTEK maupun kehidupan sehari-hari.

Melihat proses pembelajaran matematika yang dilakukan oleh tenaga pendidik cenderung pada pencapaian target kurikulum. Proses pembelajaran dalam KTSP menuntut adanya partisipasi aktif dari seluruh siswa. Jadi, kegiatan belajar berpusat pada siswa, guru hanya sebagai motivator dan fasilitator di dalam agar suasana kelas lebih hidup. Keberhasilan proses belajar mengajar selain memahami materi, juga dituntut mengetahui posisi awal siswa sebelum mengikuti pelajaran tersebut. 
Penelitian ini memfokuskan peran matematika dalam kehidupan seharihari, salah satunya dalam perhitungan warisan. Warisan merupakan Al-miirats, dalam bahasa Arab adalah bentuk mashdar (infinitif) dari kata waritsa-yaritsuirtsan-miiraatsan. Maknanya menurut bahasa ialah ‘berpindahnya sesuatu dari seseorang kepada orang lain', atau dari suatu kaum kepada kaum lain.

Dalam kehidupan sehari-hari, persoalan waris sering kali menjadi pemicu pertikaian dan menimbulkan keretakan hubungan keluarga, bahkan bisa sampai terjadi tindakan kriminal seperti pembunuhan. Sifat alamiah manusia yang selalu ingin mendapatkan sesuatu hal yang lebih banyak dalam hal duniawi dalam hal ini harta, disamping karena kekurang tahuan pihak-pihak yang terkait mengenai hukum pembagian waris, keterbatasannya pakar atau orang-orang yang mengetahui pengetahuan dan keahlian khusus yang dapat memberikan solusi atau berkonsultasi dengan orang-orang yang membutuhkan informasi pembagian waris Islam.

Banyaknya permasalahan yang timbul diakibatkan pembagian warisan yang tak seimbang, maka perlu adanya solusi. Pembelajaran berbasis masalah kiranya mampu memecahkan masalah yang ada di dalam masalah pembagian warisan. Pembelajaran Berbasis Masalah merupakan model pembelajaran yang dapat merangsang berpikir tingkat tinggi serta memungkinkan terjadinya pertukaran ide secara terbuka. Hal ini diungkapkan oleh Santrock (2008:374) Pembelajaran berbasis masalah adalah pembelajaran yang lebih menekankan pada pemecahan masalah autentik seperti masalah yang terjadi dalam kehidupan sehari-hari. ${ }^{1}$

\section{METODE PENELITIAN}

Penelitian ini dikategorikan ke dalam penelitian eksperimen semu (quasi experiment). Rancangan penelitian yang digunakan dalam penelitian ini adalah Pretes Posttest Control Group Design. Penelitian ini untuk mengetahui sejauh mana pengaruh matematika terhadap perhitungan warisan melalui pembelajaran berbasis masalah. Penelitian dilaksanakan di MA Pondok Pesantren Al-Azhar Biibadillah Tahalak Kecamatan Batang Angkola. ${ }^{1}$

\footnotetext{
${ }^{1}$ Santrock, W. (2008). Psikologi Pendidikan Edisi Kedua. Terjemahan oleh Tri Wibowo. Jakarta: Kencana.
} 
FITRAH Jurnal Kajian Ilmu-ilmu Keislaman

Vol. 05 No. 1 Juni 2019

\section{PEMBAHASAN}

\section{Data Nilai Postest}

Berdasarkan hasil penelitian pada pokok bahasan pecahan dan ilmu waris di kelas XI MA Al-Azhar Biibadillah Tahalak Kecamatan Batang Angkola, peneliti memperoleh data postest kelas eksperimen sebagai berikut:

Tabel 1 Hasil Postest Kelas Eksperimen

\begin{tabular}{|c|c|c|c|c|c|c|c|c|}
\hline \multirow{2}{*}{ No } & \multirow{2}{*}{ Kode Siswa } & \multicolumn{5}{|c|}{ Soal } & \multirow{2}{*}{ Skor } & \multirow{2}{*}{ Nilai } \\
\hline & & 1 & 2 & 3 & 4 & 5 & & \\
\hline 1 & S 01 & 10 & 5 & 10 & 10 & 10 & 45 & 90 \\
\hline 2 & $\mathrm{~S} 02$ & 10 & 2 & 8 & 10 & 1 & 31 & 62 \\
\hline 3 & S 03 & 10 & 10 & 1 & 10 & 1 & 32 & 64 \\
\hline 4 & S 04 & 10 & 10 & 1 & 10 & 5 & 36 & 72 \\
\hline 5 & S 05 & 10 & 1 & 10 & 10 & 1 & 32 & 64 \\
\hline 6 & S 06 & 10 & 1 & 10 & 10 & 10 & 41 & 82 \\
\hline 7 & S 07 & 2 & 10 & 10 & 10 & 6 & 38 & 76 \\
\hline 8 & S 08 & 10 & 6 & 6 & 10 & 10 & 42 & 84 \\
\hline 9 & S 09 & 10 & 5 & 10 & 10 & 1 & 36 & 72 \\
\hline 10 & S 10 & 10 & 5 & 10 & 10 & 10 & 45 & 90 \\
\hline 11 & S 11 & 10 & 6 & 10 & 4 & 1 & 31 & 62 \\
\hline 12 & $\mathrm{~S} 12$ & 1 & 1 & 10 & 10 & 10 & 32 & 64 \\
\hline 13 & $\mathrm{~S} 13$ & 10 & 5 & 1 & 10 & 10 & 36 & 72 \\
\hline 14 & $\mathrm{~S} 14$ & 10 & 2 & 1 & 10 & 1 & 24 & 48 \\
\hline 15 & $\mathrm{~S} 15$ & 10 & 2 & 8 & 10 & 1 & 31 & 62 \\
\hline 16 & $\mathrm{~S} 16$ & 10 & 1 & 10 & 10 & 1 & 32 & 64 \\
\hline 17 & $\mathrm{~S} 17$ & 10 & 6 & 10 & 10 & 1 & 37 & 74 \\
\hline 18 & $\mathrm{~S} 18$ & 10 & 4 & 10 & 10 & 6 & 40 & 80 \\
\hline 19 & S 19 & 10 & 6 & 10 & 10 & 1 & 37 & 74 \\
\hline 20 & S 20 & 10 & 4 & 4 & 10 & 10 & 38 & 76 \\
\hline \multicolumn{7}{|c|}{ Nilai tertinggi } & \multicolumn{2}{|c|}{90} \\
\hline \multicolumn{7}{|c|}{ Nilai terendah } & \multicolumn{2}{|c|}{48} \\
\hline \multicolumn{7}{|c|}{ Jumlah } & \multicolumn{2}{|c|}{1432} \\
\hline \multicolumn{7}{|c|}{ Rata-rata } & \multicolumn{2}{|c|}{71,6} \\
\hline \multicolumn{7}{|c|}{ Median } & \multicolumn{2}{|c|}{72} \\
\hline \multicolumn{7}{|c|}{ Modus } & \multicolumn{2}{|c|}{64} \\
\hline \multicolumn{7}{|c|}{$\mathrm{S1}$} & \multicolumn{2}{|c|}{10,57} \\
\hline \multicolumn{7}{|c|}{$\mathrm{S}^{2}{ }^{2}$} & \multicolumn{2}{|c|}{111,83} \\
\hline
\end{tabular}


Berdasarkan tabel 1 diperoleh nilai rata-rata postest di kelas pembelajaran berbasis masalah $\left(\overline{X_{1}}\right)$ sebesar 71,6 dengan nilai tertinggi 90 dan nilai terendah 48 dengan standar deviasi (SD1) sebesar 10,57, dengan median 72 dan modus 64 .

Tabel 2 Interval Postest Kelas Eksperimen

\begin{tabular}{|l|l|c|c|c|}
\hline No & Interval & frekuensi & Fk & Persentase \\
\hline 1 & $48-57$ & 1 & 1 & 5 \\
\hline 2 & $58-67$ & 7 & 8 & 40 \\
\hline 3 & $68-77$ & 7 & 15 & 75 \\
\hline 4 & $78-87$ & 3 & 18 & 90 \\
\hline 5 & $88-97$ & 2 & 20 & 100 \\
\hline
\end{tabular}

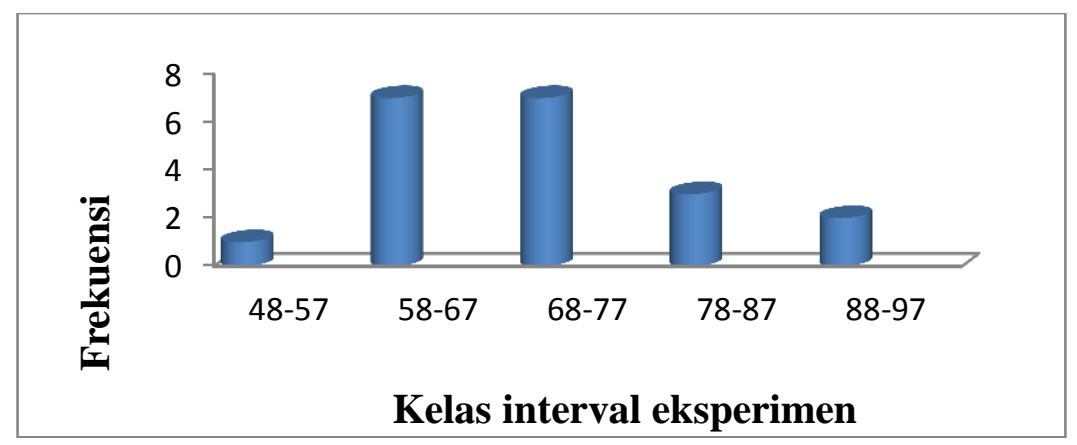

Gambar 1. Grafik Interval postes kelas eksperimen

Berdasarkan hasil penelitian pada pokok bahasan pecahan dan ilmu waris di kelas XI MA Al-Azhar Biibadillah Tahalak Kecamatan Batang Angkola, penulis memperoleh data postest kelas kontrol sebagai berikut:

Tabel 3 Hasil Postest Kelas Kontrol

\begin{tabular}{|c|c|c|c|c|c|c|c|c|}
\hline \multirow{2}{*}{ No } & \multirow{2}{*}{ Kode Siswa } & \multicolumn{5}{|c|}{ Soal } & \multirow{2}{*}{ Skor } & \multirow{2}{*}{ Nilai } \\
\cline { 3 - 8 } & & $\mathbf{1}$ & $\mathbf{2}$ & $\mathbf{3}$ & $\mathbf{4}$ & $\mathbf{5}$ & & \\
\hline 1 & SA 01 & 6 & 5 & 5 & 6 & 5 & 27 & 54 \\
\hline 2 & SA 02 & 5 & 6 & 6 & 5 & 5 & 27 & 54 \\
\hline 3 & SA 03 & 6 & 7 & 8 & 6 & 6 & 33 & 66 \\
\hline 4 & SA 04 & 6 & 6 & 6 & 7 & 6 & 31 & 62 \\
\hline 5 & SA 05 & 9 & 8 & 7 & 8 & 8 & 40 & 80 \\
\hline 6 & SA 06 & 8 & 6 & 6 & 7 & 6 & 33 & 66 \\
\hline 7 & SA 07 & 6 & 8 & 6 & 5 & 6 & 31 & 62 \\
\hline 8 & SA 08 & 8 & 7 & 7 & 9 & 8 & 39 & 78 \\
\hline 9 & SA 09 & 7 & 6 & 7 & 7 & 7 & 34 & 68 \\
\hline 10 & SA 10 & 6 & 8 & 7 & 6 & 6 & 33 & 66 \\
\hline 11 & SA 11 & 6 & 4 & 6 & 4 & 8 & 28 & 56 \\
\hline
\end{tabular}


FITRAH Jurnal Kajian Ilmu-ilmu Keislaman

Vol. 05 No. 1 Juni 2019

\begin{tabular}{|c|c|c|c|c|c|c|c|c|}
\hline 12 & SA 12 & 5 & 6 & 6 & 8 & 6 & 31 & 62 \\
\hline 13 & SA 13 & 5 & 7 & 4 & 6 & 5 & 27 & 54 \\
\hline 14 & SA 14 & 6 & 8 & 6 & 6 & 7 & 33 & 66 \\
\hline 15 & SA 15 & 7 & 7 & 7 & 6 & 8 & 35 & 70 \\
\hline 16 & SA 16 & 6 & 7 & 6 & 7 & 8 & 34 & 68 \\
\hline 17 & SA 17 & 8 & 7 & 9 & 8 & 8 & 40 & 80 \\
\hline 18 & SA 18 & 5 & 6 & 6 & 5 & 7 & 29 & 58 \\
\hline 19 & SA 19 & 8 & 7 & 7 & 8 & 7 & 37 & 74 \\
\hline 20 & SA 20 & 8 & 8 & 7 & 8 & 7 & 38 & 76 \\
\hline \multicolumn{7}{|c|}{ Nilai tertinggi } & \multicolumn{2}{|c|}{80} \\
\hline \multicolumn{7}{|c|}{ Nilai terendah } & \multicolumn{2}{|c|}{54} \\
\hline \multicolumn{7}{|c|}{ Jumlah } & \multicolumn{2}{|c|}{1320} \\
\hline \multicolumn{7}{|c|}{ Rata-rata } & \multicolumn{2}{|c|}{66} \\
\hline \multicolumn{7}{|c|}{ Median } & \multicolumn{2}{|c|}{66} \\
\hline \multicolumn{7}{|c|}{ Modus } & \multicolumn{2}{|c|}{66} \\
\hline \multicolumn{7}{|c|}{ S2 } & \multicolumn{2}{|c|}{8,485} \\
\hline \multicolumn{7}{|c|}{$\mathrm{S}^{2}$} & \multicolumn{2}{|c|}{72} \\
\hline
\end{tabular}

Berdasarkan tabel 3 diperoleh nilai rata - rata postest kelas pembelajaran biasa $\left(\overline{X_{1}}\right)$ sebesar 66 dengan nilai tertinggi 80 dan nilai terendah 54 dengan standar deviasi 72 dengan median 66 dan modus 66.

Tabel 4 Interval Postest Kelas Kontrol

\begin{tabular}{|c|c|c|c|c|}
\hline \multicolumn{1}{|l|}{ No } & Interval & frekuensi & Fk & Persentase \\
\hline 1 & $54-60$ & 5 & 5 & 25 \\
\hline 2 & $61-67$ & 7 & 12 & 60 \\
\hline 3 & $68-75$ & 5 & 17 & 85 \\
\hline 4 & $76-82$ & 3 & 20 & 100 \\
\cline { 1 - 4 } & & & \multicolumn{2}{|c|}{}
\end{tabular}

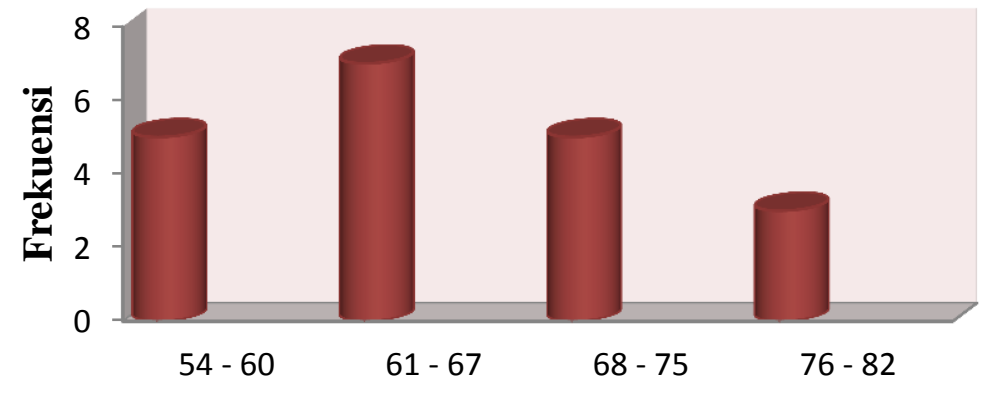

Kelas Interval Kontrol 


\section{Gambar 2 Grafik postes kelas kontrol}

Untuk lebih jelasnya dapat dilihat pada diagram Grafik Perbedaan Hasil Postest Kelas Eksperimen dan kontrol berikut ini:

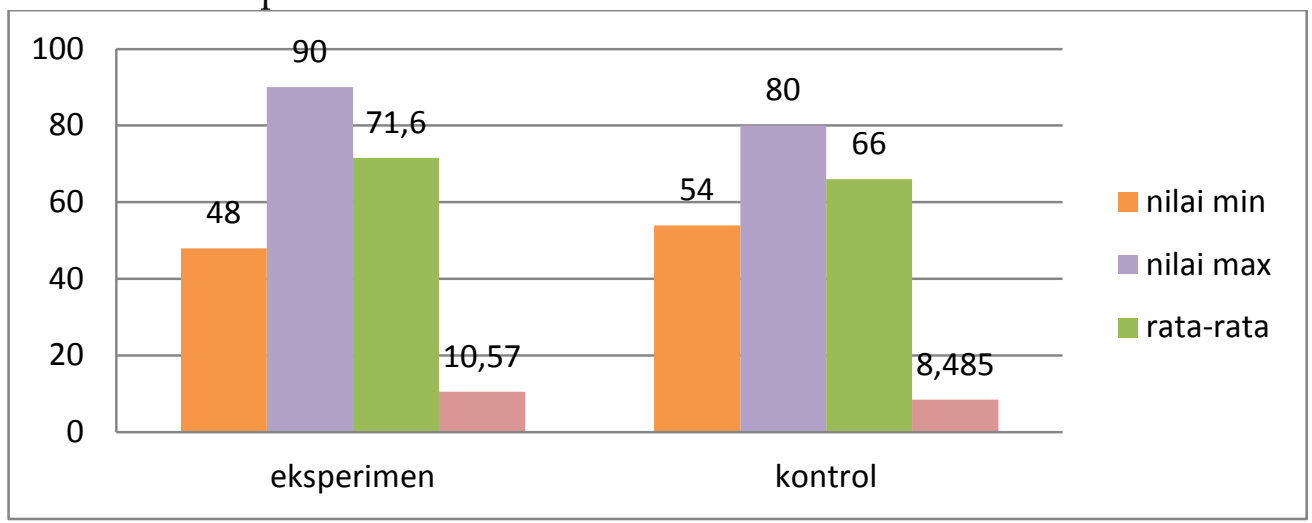

Gambar 3 Grafik Hasil Postest Kelas Eksperimen dan kontrol

Berdasarkan hasil postest siswa kelas eksperimen dan kontrol juga dapat dilihat pada tabel rangkuman berikut:

Tabel 5 Perbedaan Hasil Postest Siswa Kelas Eksperimen dan Kontrol

\begin{tabular}{|c|c|c|}
\hline Hasil Postest & Eksperimen & Kontrol \\
\hline Rata-rata & 71,6 & 66 \\
\hline Nilai tertinggi & 90 & 80 \\
\hline Nilai terendah & 48 & 54 \\
\hline Standar deviasi & 10,57 & 8,485 \\
\hline
\end{tabular}

\section{Analisis Data Lembar Observasi}

Peneliti melakukan observasi terhadap aktivitas siswa selama pembelajaran materi pecahan dan ilmu waris dengan menerapkan pembelajaran berbasis masalah di kelas XI. Dari pembelajaran pertama dan kedua maka diperoleh hasil sebagai berikut :

Tabel 6 Hasil Observasi Respon Siswa Kelas Eksperimen

\begin{tabular}{|c|c|c|c|c|c|c|c|}
\hline \multirow[b]{2}{*}{ No } & \multirow[b]{2}{*}{ Kode Siswa } & \multicolumn{2}{|c|}{ Pertemuan I } & \multirow[b]{2}{*}{ Ket. } & \multicolumn{2}{|c|}{ Pertemuan II } & \multirow[b]{2}{*}{ Ket. } \\
\hline & & $\mathbf{N}$ & $\%$ & & $\mathbf{N}$ & $\%$ & \\
\hline 1 & S 01 & 27 & 84,375 & Baik & 31 & 96,875 & Baik \\
\hline 2 & $\mathrm{~S} 02$ & 21 & 65,625 & Cukup & 26 & 81,25 & Baik \\
\hline 3 & $\mathrm{~S} 03$ & 22 & 68,75 & Cukup & 24 & 75 & Cukup \\
\hline 4 & S 04 & 23 & 71,875 & Cukup & 25 & 78,125 & Baik \\
\hline 5 & S 05 & 23 & 71,875 & Cukup & 26 & 81,25 & Baik \\
\hline 6 & S 06 & 26 & 81,25 & Baik & 30 & 93,75 & Baik \\
\hline
\end{tabular}


FITRAH Jurnal Kajian Ilmu-ilmu Keislaman

Vol. 05 No. 1 Juni 2019

\begin{tabular}{|l|l|l|l|l|l|l|l|}
7 & S 07 & 22 & 68,75 & Cukup & 23 & 71,875 & Cukup \\
\hline 8 & S 08 & 25 & 78,125 & Baik & 23 & 71,875 & Cukup \\
\hline 9 & S 09 & 22 & 68,75 & Baik & 23 & 71,875 & Cukup \\
\hline 10 & S 010 & 25 & 78,125 & Baik & 27 & 84,375 & Baik \\
\hline 11 & S 011 & 22 & 68,75 & Cukup & 26 & 81,25 & Baik \\
\hline 12 & S 012 & 21 & 65,625 & Cukup & 20 & 62,5 & Cukup \\
\hline 13 & S 013 & 25 & 78,125 & Baik & 28 & 87,5 & Baik \\
\hline 14 & S 014 & 22 & 68,75 & Cukup & 25 & 78,125 & Baik \\
\hline 15 & S 015 & 24 & 75 & Cukup & 27 & 84,375 & Baik \\
\hline 16 & S 016 & 24 & 75 & Cukup & 26 & 81,25 & Baik \\
\hline 17 & S 017 & 23 & 71,875 & Cukup & 24 & 75 & Cukup \\
\hline 18 & S 018 & 24 & 75 & Cukup & 26 & 81,25 & Baik \\
\hline 19 & S 019 & 23 & 71,875 & Cukup & 24 & 75 & Cukup \\
\hline 20 & S 020 & 25 & 78,125 & Baik & 27 & 84,375 & Baik \\
\hline
\end{tabular}

Dari tabel di atas terlihat bahwa total ke 8 indikator pada kelas eksperimen pertemuan 1 dengan keterangan baik 6 orang siswa, dan cukup berjumlah 14 orang siswa dan pada pertemuan 2 pada kelas eksperimen semua siswa dengan keterangan baik 13 orang siswa, dan cukup berjumlah 7 orang siswa. Berarti dari pertemuan 1 ke pertemuan ke 2 kelas eksperimen belajar siswa meningkat.

Tabel 7 Hasil Observasi Respon Siswa Kelas Kontrol

\begin{tabular}{|c|c|c|c|c|c|c|c|}
\hline \multirow[b]{2}{*}{ No } & \multirow[b]{2}{*}{ Kode Siswa } & \multicolumn{2}{|c|}{ Pertemuan I } & \multirow[b]{2}{*}{ Ket. } & \multicolumn{2}{|c|}{ Pertemuan II } & \multirow[b]{2}{*}{ Ket. } \\
\hline & & $\mathbf{N}$ & $\%$ & & $\mathbf{N}$ & $\%$ & \\
\hline 1 & SA 01 & 10 & 31,25 & Kurang & 12 & 37,5 & Kurang \\
\hline 2 & SA 02 & 10 & 31,25 & Kurang & 12 & 37,5 & Kurang \\
\hline 3 & SA 03 & 18 & 56,25 & Cukup & 19 & 59,375 & Cukup \\
\hline 4 & SA 04 & 13 & 40,625 & Kurang & 13 & 40,625 & Kurang \\
\hline 5 & SA 05 & 26 & 81,25 & Baik & 30 & 93,75 & Baik \\
\hline 6 & SA 06 & 15 & 46,875 & Kurang & 18 & 56,25 & Cukup \\
\hline 7 & SA 07 & 15 & 46,875 & Kurang & 16 & 50 & Kurang \\
\hline 8 & SA 08 & 29 & 90,625 & Baik & 30 & 93,75 & Baik \\
\hline 9 & SA 09 & 28 & 87,5 & Baik & 29 & 90,625 & Baik \\
\hline 10 & SA 010 & 15 & 46,875 & Kurang & 14 & 43,75 & Kurang \\
\hline 11 & SA 011 & 12 & 37,5 & Kurang & 13 & 40,625 & Kurang \\
\hline 12 & SA 012 & 14 & 43,75 & Kurang & 14 & 43,75 & Kurang \\
\hline 13 & SA 013 & 13 & 40,625 & Kurang & 16 & 50 & Kurang \\
\hline
\end{tabular}


The Effect of Mathematics on Heritage .... Masdelima Azizah Sormin, dkk

DOI: $h$ ttp://dx.doi.org/10.24952/fitrah.v5i1.1811

\begin{tabular}{|l|l|l|l|l|l|l|l|}
\hline 14 & SA 014 & 13 & 40,625 & Kurang & 13 & 40,625 & Kurang \\
\hline 15 & SA 015 & 29 & 90,625 & Baik & 30 & 93,75 & Baik \\
\hline 16 & SA 016 & 12 & 37,5 & Kurang & 15 & 46,875 & Kurang \\
\hline 17 & SA 017 & 26 & 81,25 & Baik & 29 & 90,625 & Baik \\
\hline 18 & SA 018 & 14 & 43,75 & Kurang & 14 & 43,75 & Kurang \\
\hline 19 & SA 019 & 26 & 81,25 & Baik & 29 & 90,625 & Baik \\
\hline 20 & SA 020 & 26 & 81,25 & Baik & 29 & 90,625 & Baik \\
\hline
\end{tabular}

Dari tabel di atas terlihat bahwa total ke 8 indikator belajar pada kelas kontrol pertemuan 1 dengan keterangan kurang 12 orang, yang cukup 1 orang dan baik 7 orang siswa. dan pada pertemuan 2 pada kelas kontrol baik 7 orang, cukup 2 orang siswa dan kurang 11 orang siswa.

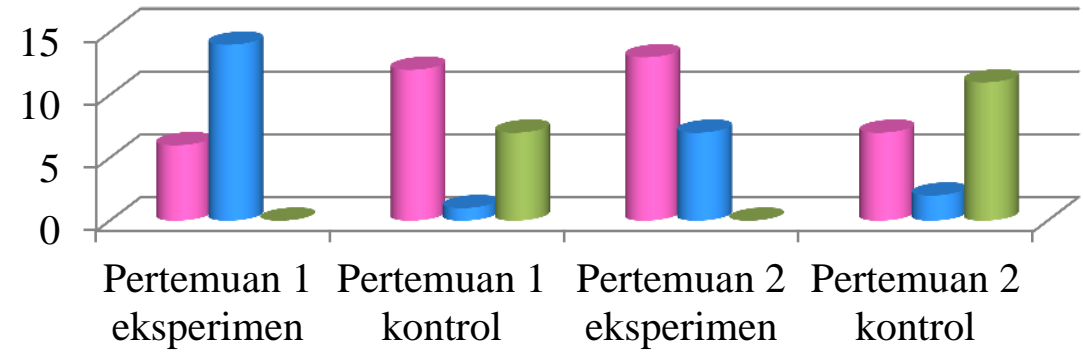

Gambar 4 Hasil Observasi Pertemuan Kelas Eksperimen Dan Kontrol

\section{Analisis Data Instrumen Penelitian}

\section{Uji Normalitas}

Uji normalitas dilakukan dengan uji Liliefors (L), dari hasil perhitungan diperoleh data kelompok sampel nilai post-test adalah sebagai berikut:

Tabel 8 Hasil Uji Normalitas Kelas Eksperimen

\begin{tabular}{|c|c|c|c|c|c|c|c|c|c|c|}
\hline No & $\mathbf{x i}$ & $\mathbf{F i}$ & $\mathbf{F k}$ & $\mathbf{F i x i}$ & $\mathbf{x i 2}$ & $\mathbf{f i x i 2}$ & $\mathbf{Z i}$ & $\mathbf{s z i}$ & $\mathbf{F z i}$ & fzi-szi \\
\hline $\mathbf{1}$ & 48 & 1 & 1 & 48 & 2304 & 2304 & $-2,2327$ & 0,05 & 0,0129 & $-0,0371$ \\
\hline $\mathbf{2}$ & 62 & 3 & 4 & 186 & 3844 & 11532 & $-0,9082$ & 0,2 & 0,1841 & $-0,0159$ \\
\hline $\mathbf{3}$ & 64 & 4 & 8 & 256 & 4096 & 16384 & $-0,719$ & 0,4 & 0,2388 & $-0,1612$ \\
\hline $\mathbf{4}$ & 72 & 3 & 11 & 216 & 5184 & 15552 & 0,03784 & 0,55 & 0,512 & $-0,038$ \\
\hline $\mathbf{5}$ & 74 & 2 & 13 & 148 & 5476 & 10952 & 0,22706 & 0,65 & 0,5871 & $-0,0629$ \\
\hline $\mathbf{6}$ & 76 & 2 & 15 & 152 & 5776 & 11552 & 0,41627 & 0,75 & 0,6591 & $-0,0909$ \\
\hline $\mathbf{7}$ & 80 & 1 & 16 & 80 & 6400 & 6400 & 0,7947 & 0,8 & 0,7882 & $-0,0118$ \\
\hline $\mathbf{8}$ & 82 & 1 & 17 & 82 & 6724 & 6724 & 0,98392 & 0,85 & 0,8365 & $-0,0135$ \\
\hline $\mathbf{9}$ & 84 & 1 & 18 & 84 & 7056 & 7056 & 1,17313 & 0,9 & 0,579 & $-0,321$ \\
\hline
\end{tabular}


FITRAH Jurnal Kajian Ilmu-ilmu Keislaman

Vol. 05 No. 1 Juni 2019

\begin{tabular}{|l|l|l|l|l|l|l|l|l|l|l|}
$\mathbf{1 0}$ & 90 & 2 & 20 & 180 & 8100 & 16200 & 1,74078 & 1 & 0,9591 & $-0,0409$ \\
\hline
\end{tabular}

Dengan Kriteria :

$\mathrm{H}_{0}<\mathrm{H}_{\mathrm{a}}=L_{o}<L_{\text {tabel }}$ maka sampel berdistribusi normal.

$\mathrm{H}_{0}>\mathrm{H}_{\mathrm{a}}=L_{o}>L_{\text {tabel }}$ maka sampel tidak berdistribusi normal.

Dari tabel di atas setelah dilakukan perhitungan maka diperoleh harga Lhitung sebesar 0,321 sedangkan Ltabel=0,190. Dengan demikian diperoleh bahwa harga Lhitung $<$ Ltabel yaitu 0,321 < 0,190 yang berarti data nilai siswa kelas

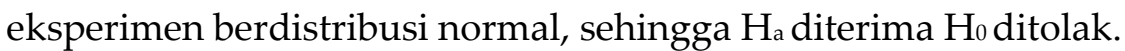

Tabel 9 Hasil Uji Normalitas Kelas Kontrol

\begin{tabular}{|c|c|c|c|c|c|c|c|c|c|c|}
\hline No & $\mathbf{x i}$ & $\mathbf{F i}$ & $\mathbf{F k}$ & $\mathbf{F i x i}$ & $\mathbf{x i 2}$ & $\mathbf{f i x i 2}$ & $\mathbf{Z i}$ & Szi & Fzi & fzi-szi \\
\hline $\mathbf{1}$ & 54 & 3 & 3 & 162 & 2916 & 8748 & $-1,4143$ & 0,15 & 0,0793 & $-0,0707$ \\
\hline $\mathbf{2}$ & 58 & 1 & 4 & 56 & 3136 & 3136 & $-1,1786$ & 0,2 & 0,121 & $-0,079$ \\
\hline $\mathbf{3}$ & 62 & 1 & 5 & 58 & 3364 & 3364 & $-0,9428$ & 0,25 & 0,1736 & $-0,0764$ \\
\hline $\mathbf{4}$ & 64 & 3 & 8 & 186 & 3844 & 11532 & $-0,4714$ & 0,4 & 0,3192 & $-0,0808$ \\
\hline $\mathbf{5}$ & 66 & 4 & 12 & 264 & 4356 & 17424 & 0 & 0,6 & 0,5 & $-0,1$ \\
\hline $\mathbf{6}$ & 68 & 2 & 14 & 136 & 4624 & 9248 & 0,23571 & 0,7 & 0,591 & $-0,109$ \\
\hline $\mathbf{7}$ & 70 & 1 & 15 & 70 & 4900 & 4900 & 0,47142 & 0,75 & 0,6808 & $-0,0692$ \\
\hline $\mathbf{8}$ & 74 & 1 & 16 & 74 & 5476 & 5476 & 0,94284 & 0,8 & 0,8264 & $\mathbf{0 , 0 2 6 4}$ \\
\hline $\mathbf{9}$ & 76 & 1 & 17 & 76 & 5776 & 5776 & 1,17855 & 0,85 & 0,579 & $-0,271$ \\
\hline $\mathbf{1 0}$ & 78 & 1 & 18 & 78 & 6084 & 6084 & 1,41426 & 0,9 & 0,9207 & 0,0207 \\
\hline
\end{tabular}

Dengan Kriteria :

$\mathrm{H}_{0}<\mathrm{H}_{\mathrm{a}}=L_{o}<L_{\text {tabel }}$ maka sampel berdistribusi normal.

$\mathrm{H}_{0}>\mathrm{H}_{\mathrm{a}}=L_{o}>L_{\text {tabel }}$ maka sampel tidak berdistribusi normal.

Dari tabel di atas setelah dilakukan perhitungan maka diperoleh harga Lhitung sebesar 0,0264 sedangkan Ltabel $=0,190$. Dengan demikian diperoleh bahwa harga Lhitung $<$ Ltabel yaitu 0,0264 $<0,190$ yang berarti data nilai siswa kelas kontrol berdistribusi normal, sehingga $\mathrm{H}_{\mathrm{a}}$ diterima $\mathrm{H}_{0}$ ditolak.

Untuk lebih jelasnya disimpulkan pada tabel sebagai berikut :

Tabel 10 Distribusi Normalitas Pos-test Kelas Eksperimen dan kontrol

\begin{tabular}{|c|c|c|c|}
\hline & Post-Test & L & Keterangan \\
\hline Kelas Eksperimen & 0,321 & 0,190 & Normal \\
\hline Kelas Kontrol & 0,0264 & 0,190 & Normal \\
\hline
\end{tabular}

Berdasarkan data pada tabel 5.10 di atas menunjukkan bahwa $\mathrm{L}_{0}<$ Ltabel yang artinya data kedua kelompok sampel Post-Test kelas eksperimen $\mathrm{L}_{0}=$ 0,0264 < Ltabel 0,190, kelas kontrol $\mathrm{L}_{\mathrm{o}}=0,0264<$ Ltabel 0,190 , berasal dari populasi yang berdistribusi normal. 


\section{Uji Homogenitas}

Pengujian homogenitas diperoleh hasilnya dalam tabel berikut :

Tabel 11 Uji Homogenitas Kelas Eksperimen dan Kontrol

\begin{tabular}{|c|c|c|}
\hline & Eksperimen & Kontrol \\
\hline $\mathrm{N}$ & 20 & 20 \\
\hline $\bar{X}$ & 71,6 & 66 \\
\hline $\mathrm{S}$ & 10,57 & 8,485 \\
\hline $\mathrm{S}^{2}$ & 111,83 & 72 \\
\hline
\end{tabular}

Dengan Kriteria :

$H_{o}: \sigma_{1}{ }^{2}=\sigma_{2}{ }^{2}$, artinya varians dua kelas eksperimen yang homogen $H_{a}: \sigma_{1}^{2} \neq \sigma_{2}^{2}$, artinya varians dua kelas eksperimen tidak homogen.

Dari hasil perhitungan diperoleh $F_{\text {hitung }}=1,69$ sedangkan $F_{\text {tabel }}=2,03$ pada taraf nyata $\alpha=0,05$ sebesar, Karena Fhitung $=1,69<\mathrm{F}_{\text {tabel }}=2,03$ maka disimpulkan nilai postest kedua kelas sampel homogen.

\section{Pengujian Hipotesis}

Hipotesis di atas adalah hipotesis alternatif. Hipotesis tersebut dapat diterima apabila $F_{\text {hitung }}>\mathrm{F}_{\text {tabel }}$ dengan taraf signifikan $\alpha=0,05, \mathrm{dk}=\mathrm{N}-2=20-2$ $=18$. Begitu juga sebaliknya apabila $F_{h i t u n g}<F_{\text {tabel }}$ maka hipotesis ditolak. Untuk itu perlu dilakukan penghitungan skor dan nilai akhir masing-masing dari variabel $\mathrm{x}$ dan $\mathrm{y}$ dan untuk lebih jelasnya dapat dilihat dari tabel kerja regresi sederhana sebagai berikut:

Tabel 12 Tabel Kerja regresi sederhana

\begin{tabular}{|c|c|c|c|c|c|}
\hline No & $\mathbf{X}$ & $\mathbf{Y}$ & $\mathbf{X}^{\mathbf{2}}$ & $\mathbf{Y}^{\mathbf{2}}$ & $\mathbf{X Y}$ \\
\hline 1 & 45 & 27 & 2025 & 729 & 1215 \\
\hline 2 & 31 & 27 & 961 & 729 & 837 \\
\hline 3 & 32 & 33 & 1024 & 1089 & 1056 \\
\hline 4 & 36 & 31 & 1296 & 961 & 1116 \\
\hline 5 & 32 & 40 & 1024 & 1600 & 1280 \\
\hline 6 & 41 & 33 & 1681 & 1089 & 1353 \\
\hline 7 & 38 & 31 & 1444 & 961 & 1178 \\
\hline 8 & 42 & 39 & 1764 & 1521 & 1638 \\
\hline 9 & 36 & 34 & 1296 & 1156 & 1224 \\
\hline 10 & 45 & 33 & 2025 & 1089 & 1485 \\
\hline 11 & 31 & 28 & 961 & 784 & 868 \\
\hline 12 & 32 & 31 & 1024 & 961 & 992 \\
\hline
\end{tabular}


FITRAH Jurnal Kajian Ilmu-ilmu Keislaman

Vol. 05 No. 1 Juni 2019

\begin{tabular}{|c|c|c|c|c|c|}
\hline 13 & 36 & 27 & 1296 & 729 & 972 \\
\hline 14 & 24 & 33 & 576 & 1089 & 792 \\
\hline 15 & 31 & 35 & 961 & 1225 & 1085 \\
\hline 16 & 32 & 34 & 1024 & 1156 & 1088 \\
\hline 17 & 37 & 40 & 1369 & 1600 & 1480 \\
\hline 18 & 40 & 29 & 1600 & 841 & 1160 \\
\hline 19 & 37 & 37 & 1369 & 1369 & 1369 \\
\hline 20 & 38 & 38 & 1444 & 1444 & 1444 \\
\hline & 716 & 660 & 26164 & 22122 & 23632 \\
\hline
\end{tabular}

$$
\begin{gathered}
a=\frac{N \Sigma X Y-\Sigma X(\Sigma Y)}{\sqrt{\left\{\left(N \Sigma X^{2}-\left((\Sigma X)^{2}\right\}\left(\left(N \Sigma Y^{2}-(\Sigma Y)^{2}\right.\right.\right.\right.}}=0,0094 \\
b=\frac{N \Sigma X Y-\Sigma X(\Sigma Y)}{N \Sigma X^{2}-\left((\Sigma X)^{2}\right.}=0,0075 \\
\vec{y}=a+b x=0,5344
\end{gathered}
$$

Menguji sigfnifikan dengan langkah sebagai berikut :

Langkah 1: JK $K_{\operatorname{Reg}(a)}=\frac{\left(\sum y\right)^{2}}{n}=21780$

Langkah $2: J K_{R e g(b \mid a)}=b\left(x y-\frac{\left(\sum x\right)\left(\sum y\right)}{n}\right)=2,1$

Langkah 3:JK Res $=\sum y^{2}-J K_{R e g(b \mid a)}-J K_{R e g(a)}=339,9$

Langkah $4: R J K_{R e g(a)}=J K_{R e g(a)}=21780$

Langkah $5: J K_{R e g(b \mid a)}=J K_{R e g(b \mid a)}=2,1$

Langkah $6: R J K_{\text {Res }}=\frac{J K_{\text {Res }}}{n-2}=18,88$

Maka, $F_{\text {hitung }}=\frac{R J K_{R e g(b \mid a)}}{R J K_{\text {Res }}}=0,111$

Untuk menghitung $F_{\text {tabel }}$ :

$$
F_{\text {hitung }}=F_{(1-\alpha) /\left(d k_{\text {reg }(b \mid a)}\right) \cdot\left(d k_{\text {res }}\right)}
$$

$\mathrm{Dk}$ reg $(\mathrm{b} \mid \mathrm{a})=1$

$\mathrm{Dk}_{\text {res }}=20-2=18$

Maka, $F_{\text {tabel }}$ pada tabel terletak pada dk 1 (pembilang), dk 18 (penyebut) = 4,41

Sehingga :

$F_{\text {tabel }}=F_{(1-\alpha) /\left(d k_{r e g(b \mid a)}\right) \cdot\left(d k_{r e s}=n-2=18\right)}$

$F_{\text {tabel }}=F_{(1-0,05) /(1) \cdot(18)}$

$F_{\text {tabel }}=F_{(0,95) /(4,41) \cdot(4,41)}$

$F_{\text {tabel }}=F_{(0,048)}$

$$
=0,048
$$

$F_{\text {hitung }}>\mathrm{F}_{\text {tabel }}=0,111>0,048$. maka $\mathrm{H}_{0}$ artinya signifikan.

$\mathrm{H}_{0}$ : Tidak ada pengaruh matematika terhadap perhitungan warisan melalui Pembelajaran Biasa di kelas XI MA Pondok Pesantren Al-Azhar Biibadillah Tahalak Kecamatan Batang Angkola. 
$\mathrm{H}_{a}$ : ada pengaruh matematika terhadap perhitungan warisan melalui Pembelajaran Berbasis Masalah di kelas XI MA Pondok Pesantren AlAzhar Biibadillah Tahalak Kecamatan Batang Angkola.

Langkah 8 : Kesimpulan

Karena Fhitung $>F_{\text {tabel }}=0,111>0,048$. maka $\mathrm{H}_{0}$ ditolak dan $\mathrm{H}_{\mathrm{a}}$ diterima.

Dengan demikian terdapat pengaruh matematika terhadap perhitungan warisan melalui Pembelajaran Berbasis Masalah di kelas XI MA Pondok Pesantren Al-Azhar Biibadillah Tahalak Kecamatan Batang Angkola yang signifikan.

\section{UCAPAN TERIMA KASIH}

Penelitian ini terlaksana dengan bantuan berbagai pihak, terima kasih kepada pihak yang sudah membantu. Direktorat Riset dan Pengabdian Masyarakat, Direktorat Jendral Penguatan Riset dan Pengembangan Kenentrian Riset, Teknologi dan Pendidikan Tinggi sesuai dengan kontrak Nomor: T/ 79/ L1.3.1/ PT.01.03/2019. 
FITRAH Jurnal Kajian Ilmu-ilmu Keislaman

Vol. 05 No. 1 Juni 2019

\section{DAFTAR PUSTAKA}

Santrock, W. (2008). Psikologi Pendidikan Edisi Kedua. Terjemahan oleh Tri Wibowo. Jakarta: Kencana.

Rusman, (2011). Model-model Pembelajaran Mengembangkan Profesional Guru. Jakarta: PT. Raja Grafindo Persada.

Ash-Shabuni.A.M. (2013). Hukum Waris Dalam Islam. Depok Jawa Barat: PT . Fathan Prima Media.

Saebani. B.A. (2009). Figh Mawaris. Bandung: Pustaka Setia.

Trianto, (2009). Mendesain Model Pembelajaran Inovatif-Progresif. Jakarta: Kencana Prenada Media Group.

Kunandar. 2010, Guru Profesional Implementasi Kurikulum Tingkat Satuan Pendidikan (KTSP) dan Sukses dalam Sertifikasi Guru. Rajawali Pers: Jakarta

Arikunto, Suharsimi, (2009), Manajemen Penelitian, Jakarta: Rineka Cipta. 